phenomenon was at its brightest. (2) The complete continuity of the mock sun ring, the portion within the $22^{\circ}$ halo being quite distinct. (3) The fact that the arc of upper contact had its concave side towards the sun, and extended for more than $90^{\circ}$ on either side of the point of contact, gradually growing more diffuse and faint. This seems to be quite a special characteristic. (4) The peculiar shape of the mock suns and the positions of the two nearer the sun. These were not on the $22^{\circ}$ halo, but outside the arc of upper contact, as shown in the sketch, the arc bisecting the distances measured along the ring between the mock suns and the halo.

At 0.30 p.m. the sky again became overcast, nor could any trace of the phenomenon be seen afterwards. In the afternoon and evening the wind was very cold, and there was a fair amount of cloud, but on the whole it was fine and sunny. The night, however, was wet and stormy.

Stonyhurst College Observatory, August 30.

\section{W. McKeon.}

\section{Man and Environment.}

I AM under the impression that it is recorded somewhere that Darwin expressed the following opinion:- $\mathrm{He}$ considered the fact that when man appears he appears, not as a "blind" subject of his environments, but with power to determine largely, not only his own environments, but those of generations of men succeeding his own generation; and, faced by this fact, he expressed a doubt whether, when man appears, some new factor may not come into play in " natural selection " (cf. "The Descent of Man," and ed., p. 613, lines $I_{5}$ to end of paragraph). But I cannot find the reference. Could any reader of NATURE assist me?

Wick Court, near Bristol.

THE ATTAINMENT OF THE NORTH POLE.

$D$ URING the past week great attention has been given to the announcement on September I that Dr. F. A. Cook had returned from north polar regions, having reached the North Pole on April $2 \mathrm{I}$, 1908. The interest excited by this statement has since been increased by a message, dated September 6, received at New. York from Commander Peary, reporting that he reached the pole on April 6, I909.

Commander Peary departed for the north from Sydney, Cape Breton, on July I7, I908, his intention being to proceed by the Smith Sound route to his winter quarters on the northern shore of Grant Land. He hoped to start for the pole with fully-loaded sledges from the "Big head" he encountered in the Polar Ocean in Igo6, to the north of Grant Land, in about latitude $84^{\circ} \mathrm{N}$. The last information concerning him indicated that in the middle of August last year his ship, the Roosevelt, was continuing her voyage northwards from Etah, the expedition's base of supplies on Smith Sound. He took sounding apparatus with him, with the intention of obtaining a line of soundings from Grant Land to the pole. When he left last vear he stated that; should he reach the pole, news of his success might be expected between August $I_{5}$ and September ${ }_{15}$, and the message received on September 6 has justified his expectations.

It is difficult yet to arrive at a satisfactory opinion as to the value of the observations from which the explorers conclude that they reached the North Pole, but as both Dr. Cook and Commander Peary are responsible travellers, it must be assumed that they realise the difficulty of determining the position of the pole, and took the necessary precautions to establish the validity of their claims. We have no right to doubt their statements, but the publication of the observations at an early date is greatly to be desired, so that the matter can be placed beyond question. In the case of Commander Peary, his previous work in Arctic regions is so well known that geographers NO. 2080, VOL. 8I] have accepted his announcement without hesitation, and a congratulatory message has been sent to him by the Royal Geographical Society. On the occasion of his previous expedition in 1906 , he approached to within two hundred miles of the pole, and there was every reason to anticipate that this year he would reach the pole itself. His plans were known, and his long experience of Arctic conditions justified confidence in their successful accomplishment. There has, however, been much discussion upon Dr. Cook's journey and achievement, and as he claims to have reached the North Pole nearly a year before Commander Peary, it is of interest to give a few particulars relating to him and his expedition.

Dr. Cook is an American medical man, with varied experience of exploring work in both the Arctic and Antarctic regions. He served as surgeon on Commander Peary's second expedition to West Greenland in $189 \mathrm{I}$, and was a member of the Belgian Antarctic expedition under Commander De Gerlache, which spent the Antarctic winter of 1898 drifting about on board the Belgica in the ice-covered seas to the southwest of Graham Land. Both in 1903 and 1906 Dr. Cook conducted expeditions to Alaska, with the object of achieving the ascent of Mount McKinley, 20,39o feet high, the loftiest mountain on the North. American Continent, and after repeated failures reported that he had succeeded in reaching the summit. Two years ago it was announced that he was desirous of organising an expedition to the South Pole, and it came as a surprise to most people to learn in the autumn of rgo7 that he was encamped at Etah, on the northwest coast of Greenland, and proposed to make a "dash" for the North Pole.

Briefly, Dr. Cook's story is that he left his base at Etah on February ig of last year, accompanied oniy by a force of Eskimos, and dogs for pulling the sledges. The route varied slightly from that adopted by Commander Peary. Dr. Cook struck westwards across Smith Sound to Ellesmere Land, and continued westwards across that island to Nansen Sound, which separates Ellesmere Land from Axel Heiberg Land, one of the new lands discovered by the Sverdrup expedition on board the Fram in 1898-1902. Fron Cape Hubbard, the northernmost point of Axel Heiberg Land, Dr. Cook pushed out over the polar ice on March 18. Three days later the last of the supporting parties returned, and Dr. Cook continued his march to the pole with only a couple of Eskimos. Between the 84 th and 85 th parallels of north latitude, he sighted land to the west, but " the urgent need of rapid advance on our main mission did not permit a detour to explore the coast." This, continues Dr. Cook, in the narrative which he has supplied to the New York Herald, was the last sign of solid earth seen on the northward march, though, "from the 87 th to the 88th parallel much surprise was. caused by an indication of land ice. For two days we travelled over ice which resembled a glacial surface. . . There was, however, no perceptible elevation, and no positive sign of land or sea." Farther north, Dr. Cook says, "signs of land were still seen every day, but they were deceptive illusions, or a mere verdict of fancy. . . The mirages turned things topsy-turvy, inverted mountains, and queer objects even rose and fell in shrouds of mystery; but all of this was due to the atmospheric magic of the midnight sun."

Finally, to quote the words used by Dr. Cook on September 7 , in a lecture to the Royal Geographical Society of Denmark:- "On April 2I my observation gave $89^{\circ} 59^{\prime} 40^{\prime \prime}$-that is, $20^{\prime \prime}$ from the pole. We advanced the $20^{\prime \prime}$ and I made another observation, and several others that day and the next. I think there is no doubt that these observations will prove that we 
have been on and around $90^{\circ}$-the North Pole." The return march was then begun. Instead of being carried by an easterly drift to the Greenland coast, the little party found themselves some distance west of Axel Heiberg Land. Continuing south to Jones Sound, they wintered in primitive fashion at Cape Sparbo, on the coast of North Devon, and subsequently made their way across to the Greeniand coast, whence Dr. Cook obtained a passage to Copenhagen on board a Danish Government steamer.

Not so much the fact that Dr. Cook was unaccompanied by any white companion as certain surprising features in the above story make it advisable to await the examination of Dr. Cook's instruments and journal of observations before his claim to have reached the pole is definitely admitted. Cape Hubbard, from which Dr. Cook pushed out into the Polar Ocean, is situated in about latitude $81^{\circ}{ }^{\circ} 5^{\prime}$ N., i.e. $5^{2} 5$ geographical or rather more than 600 statute miles from the pole. To have covered this in thirtyfive days Dr. Cook must have advanced northwards at an average rate of seventeen statute miles a day, making no allowance for deviations from a due north and south line. An even greater rate of travel was maintained for a longer period of time by Lieutenant Mecham on a sledge journey among the islands of Arctic Canada during the long series of the Franklin search expeditions. Nothing like such a rate of progression northwards has, however, been achieved by any previous traveller over the ice of the open polar sea. Nor is it correct to say, as Dr. Cook is reported to have said, that he was able to rely on more favourable conditions because he travelled earlier in the year than previous explorers. Dr. Nansen and Lieutenant Johansen left the Fram in about $84^{\circ}$ north on March I4, I895, and reached their farthest north in latitude $86^{\circ} 5^{\prime}$ north on April 8, their average daily northing being thus about six miles. Captain Cagni, of the Duke of the Abruzzi's expedition, left the winter quarters of the Stella Polure in Teplitz Bay, Franz Josef Land, latitude $8 \mathrm{I}^{\circ} 47^{\prime}$ north, on March II, I900, and reached his farthest north in latitude $86^{\circ} 33^{\prime}$ on April 25, his average daily northing having been about seven miles. In $1906 \mathrm{Commander}$ Peary pushed out over the polar ice from the northern coast of Grant Land, just south of the 83rd parallel, on March 6, and reached his farthest north in latitude $87^{\circ} 6^{\prime}$ on April $2 \mathrm{r}$, his average daily northing having been about six miles.

From these records it will be seen that by travelling northwards over the Polar Ocean at the rate of seventeen miles a day, Dr. Cook has far surpassed the most strenuous efforts of his predecessors. All the explorers mentioned were capable of, and did on occasion perform, journeys of twenty and more miles a day. But in advancing northward they all found themselves greatly delayed by open lanes of water and pressure ridges in the ice. Dr. Cook says very little about any difficulties of this nature, although he does on one occasion mention that "much of our hard work was lost in circuitous twists around troublesome pressure lines and high irregular fields of very old ice. The drift, too, was driving eastward with sufficient force to give some anxiety." If the conditions he encountered throughout his march were similar to those experienced by previous travellers over the Polar Ocean, it is astounding that he should have been able to travel so much faster than they.

Of course, conditions vary in different seasons and along different routes, and Dr. Cook may have been exceptionally favoured. There is no need to doubt his good faith, but for confirmation of his calculations it will be necessary to await the examination of his records. The precision with which he reports his NO. 2080 , VOL. $8 \mathrm{I}]$ position on April 2s would seem to show that he scarcely appreciates the difficulty of securing exact observations under the conditions as regards refraction, \&c., which prevail near the pole.

However this may be, and whatever the precise point attained by Dr. Cook, there seems little doubt that he made an extended journey over the polar ice; but scientific research was not Dr. Cook's object, and his journey can possess little scientific value. He carried no sounding apparatus, and has brought back only the vaguest information about the new lands to the north-west of Greenland. The land which he did

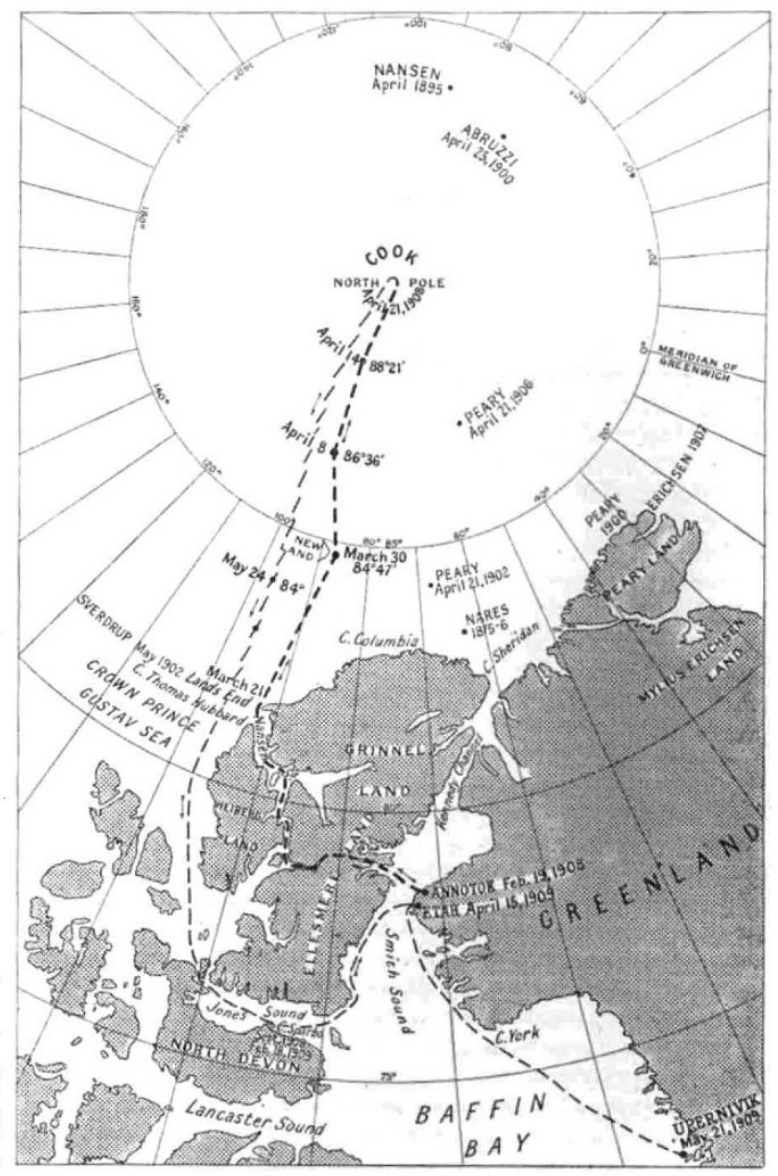

North Polar Map. Dr. Cook's rotte is shown by broken lines. Commander Peary's route is not indicated, because the details are not yet available.

sight, indeed, was probably the land which Peary sighted in 1906, or some extension thereof. Further north, there is a suggestion that the party travelled over glacial ice, but Dr. Cook has nothing definite to report which indicates the existence near the pole of anything but the ice-covered Polar Ocean. Some points have still to be cleared up. In more than one report Dr. Cook is credited with stating that the land he sighted after leaving Axel Heiberg Land abounds with game; yet he did not come within several miles of the land, and, according to the Times, met with no game beyond Heiberg Island. If Dr. Cook reached the pole, he has given a remarkable illustration of pluck and endurance, but his journey seems likely to have a minimum of scientific value, and there is still room where he has been for a wellequipped scientific research expedition to do excellent work in studying the geographical problems of the 
region. A mere "dash" to the pole may awaken a certain amount of sentimental interest, and direct public attention to the traveller, but it is of no value from the scientific point of view unless explorationphysical or geographical-is carried on. Commander Peary appears to have been equipped with apparatus for taking soundings and making other observations of polar conditions, and he has telegraphed to the director of the American Museum of Natural History, New York, "I am bringing a large amount of material for the museum." The scientific importance of polar expeditions must be judged by the new knowledge obtained rather than by the determination of a mathematical point more or less accurately according to the instruments used and precautions taken. Assuming that the North Pole has been reached by one or both the explorers, the way is now clear for the scientific study of Arctic hydrography, meteorology, and many other problems of terrestrial physics without the disturbing effort to attain the highest latitude.

\section{THE WHISKEY COMMISSION.}

THE Royal Commission on Whiskey and other Potable Spirits, the final report of which has just been issued, originated out of the attempts made by various local authorities to obtain legal decisions as to what should or should not constitute brandy and whiskey. In the case of the other recognised forms of ordinary potable spirits, no acute differences of opinion appear to have arisen. When a man asked for rum or gin the legal mind representing the man in the street was content to assume that that longsuffering individual received an article of the nature, substance, and quality he demanded. As a matter of fact, the man in the street raised no difficulty even about the two forms of potable spirits which have more particularly engaged the prolonged attention of the Royal Commission. He had absolutely no interest in the touching solicitude which was displayed on his behalf by a number of professional gentlemen, who, apparently from purely altruistic motives, were determined that he should be awakened to a proper sense of the importance of knowing the origin and mode of manufacture of articles which he had hitherto been perfectly content to purchase because he was satisfied with their quality and price.

What is brandy and what is whiskey have been the occasional subjects of discussion in the public journals and in the trade organs at intervals during the past three or four years, but it has been impossible to arouse any public feeling on these momentous questions. The fact is, the agitation, such as it was, was wholly artificial. It simply originated in, and turned upon, a struggle between competing trade interests. Brandy, by use and wont, has been universally regarded as a spirit obtained by the distillation of fermented grape-juice; whiskey as a spirit obtained by the distillation of a fermented " wash" derived from some form of cereal, usually, but not invariably or wholly, malted barley. But owing to the unfortunate grape disease (Phylloxera) which, a generation ago, devastated the French vineyards, especially in the Charentes, where the particular grapes mainly employed in the manufacture of Cognac are grown, the manufacture of factitious brandy was greatly stimulated. This consisted of some form of distilled spirit-obtained usually from grain, or from beetroot molasses, or, occasionally, from potatoes, artificially flavoured with "brandy essence" and coloured with caramel. This article entered into competition, not only with the genuine product, but with a factitious brandy "drawn and made from malted corn," which has been produced for more than a couple of centuries in this country under the name of "British brandy," a term first legally sanctioned by the Spirits Acts of I86o. In due time the vineyards were re-planted, the Charente vines being grafted on American stocks, and the manufacture of Cognac by the time-honoured methods was re-established. Naturally the manufacturers contended that their product was the only legitimate brandy, and that the factitious articles were not entitled to the name of Cognac, or when sold in this country to the term brandy, unless this was qualified, as in the case of " British brandy," by some prefix which should serve to differentiate it from the product of the grape.

This, then, as regards brandy, is the fons et. origo of the trouble. It was useless for the contending parties to appeal to our law, since, as the Commission states, there is no statutory definition of the term "brandy"; nor is there any binding judicial decision on the subject. The I48th Section of the Spirits Act of 1860 , it is true, contained an implied definition of "British brandy," which would have covered the case of all factitious bzandies sold in this country, whether made here or not, but this was repealed in $\mathrm{r} 880$, so that there is no longer a legal definition even of "British brandy."

As regards whiskey, the cause of contention was not so much the nature of the material from which the spirit was derived, although this did to some extent enter into consideration, as the manner in which the distillation was effected. Originally all whiskey was made by means of comparatively small stills-of the type known as pot-stills-in which the fermented wort was distilled by the direct application of fire. But about the year I83I, Eneas Coffey invented and patented a form of still adapted for continuous working, in which the alcohol is driven out of the wort by means of steam, and the mixture of steam and spirit is then separated by an ingeniously contrived condensing or rectifying arrangement which enables a much "cleaner" spirit to be produced-that is, a spirit much more free from what are held to constitute the characteristic constituents of whiskey, as distinguished from plain spirit. This process not only resulted in the production of a purer form of alcoholthat is, purer in the sense commonly understood by chemists-but it was more economical in use, and consequently materially cheapened the cost of production. This, of course, made the "patent still" a formidable competitor of the "pot-still," and those who had a vested interest in the pot-still naturally complained that this interest was jeopardised by the employment of a piece of apparatus which might make alcohol, but, it was contended, did not necessarily make whiskey.

In the autumn of 1905 the Islington Borough Council was induced to bring two test cases before a London stipendiary under Section 6 of the Sale of Food and Drugs Acts, in one of which it was held that a certain publican had sold, to the prejudice of a purchaser who demanded Irish whiskey, something which was not of the nature, substance, and quality of Irish whiskey; and, in the other, that another publican had sold, to the prejudice of a purchaser who demanded Scotch whiskey, something which was not of the nature, substance, and quality of Scotch whiskey. In each case the analyst had certified that what was sold as whiskey " consisted entirely of patent-still, silent or neutral spirit," and was not, therefore, in his opinion, whiskey.

The learned magistrate ruled that patent-still spirit alone is not whiskey; and that the produce of a patent still cannot be Irish or Scotch whiskey, although made in Ireland or Scotland. He further held that NO. 2080, VOL. SI] 